Research Journal of Applied Sciences, Engineering and Technology 7(14): 2970-2975, 2014

DOI:10.19026/rjaset.7.628

ISSN: 2040-7459; e-ISSN: 2040-7467

(C) 2014 Maxwell Scientific Publication Corp.

\begin{tabular}{lll}
\hline Submitted: September 16, 2013 & Accepted: October 04, 2013 & Published: April 12, 2014
\end{tabular}

Research Article

\title{
Radiological and Toxic Risk Assessment of Nigerian Kohl as Cosmetic Compared with Imported Kohl Cosmetics
}

\author{
${ }^{1}$ I.Y. Zakari, ${ }^{2}$ A.M. Sadiq, ${ }^{1}$ R. Nasiru and ${ }^{1}$ U. Sadiq \\ ${ }^{1}$ Department of Physics, Ahmadu Bello University, Zaria, Nigeria \\ ${ }^{2}$ Department of Physics, Federal College of Education, Kano, Nigeria
}

\begin{abstract}
A total of 38 different samples of Kohl comprising of 23 indigenous mined products and 15 imported products as control and were analyzed for general elemental composition but with particular interest in those reported to be of relevance ( $\mathrm{As}, \mathrm{Cd}, \mathrm{Hg}, \mathrm{Ni}, \mathrm{Co}$ and $\mathrm{Sb}$ ) in cosmetics. Energy dispersive $\mathrm{X}$-ray Fluorescence Analysis EDXRA was used for the assay. Only $\mathrm{Pb}, \mathrm{As}$, $\mathrm{Ni}$ and $\mathrm{Cr}$ were detected among the elements of interest. Mean $\mathrm{Pb}$ concentrations of $277300 \mathrm{ppm}$; $\mathrm{Ni}$ at $2256 \mathrm{ppm}$ concentration; and As at $810 \mathrm{ppm}$ which are considerably higher than their safety limits $(20 \mathrm{ppm} p<0.01)$ were obtained in both the indigenous and imported products. The same risk was statistically observed to be involved following the use of both local and imported kohl products. Again $\mathrm{Pb}$ concentrations in excess of what was claimed on the labels of the imported kohl products were observed $(\mathrm{p}<0.01)$, hence the need for scrutiny of imported products by the relevant agency. The high concentration of $\mathrm{Cr}$ $(7460 \mathrm{ppm}, \mathrm{p}<0.05)$ in the imported samples signifies its presence as colorant and the need for chromium control for the brands concerned. Also the observed presence of Th in the indigenous (local) samples suggests that Nigerian products may be of radiological effect to health. Measurements were made of gross alpha and beta count of indigenous mined and imported kohl samples The results reveals that all the forms of kohl products assayed, emit both particles but with $\beta$ 's count substantially higher than the $\alpha$ 's $(\mathrm{p}<0.5)$ at a mean $\beta$ count $4695 \times 10^{-3} \mathrm{cpm}$ and $\alpha$ count as $283 \times 10^{-3} \mathrm{cpm}$. One of the samples from Zamfara State of Nigeria (known for Pb poisoning due to mining activities) shows an exceptionally high count in both $\alpha=8998100 \mathrm{cpm}$ and $\beta=9315700 \mathrm{cpm}$ which reveals that products from Zamfara State, need a special attention. Application of this product is therefore very much likely to produce radiation damage to the cornea due to low penetration of $\alpha$ and to the internal tissue of the eye due to the relatively high penetration of $\beta$ s. However, the non-existence of defined safety limits for these particles in Kohl as cosmetic, suggests the need for further research.
\end{abstract}

Keywords: EDXRF, eye, kohl, proportional counter, radiation disease, toxic elements

\section{INTRODUCTION}

Kohl is a dark powdery substance that has been worn around the eyes for beautification (Kapoor, 2007). It was not until towards the end of the $21^{\text {st }}$ century that the very substance, kohl, that indigenous people (particularly Nigerians) used for centuries as cosmetic, for medicinal and cultural purposes, with so much belief in its benefits was discredited as a source of lead $(\mathrm{Pb})$ poisoning.

Earliest reports Warley et al. (1968), Snodgrass et al. (1973) and Betts et al. (1973) that gave rise to this, is traced to the death of an Asian child and plumbism (lead poisoning) among the Indian and Pakistani children in England to the liberal use of kohl.

Since then series of reports from kohl using countries have been emerging (Parry and Eaton, 1991; Madany and Salim, 1992; Al-Kaff et al., 1993; AlSaleh et al., 1993; Al-Hazzaa and Krahn, 1995; Hardy et al., 1998, 2002; Al-Ashban et al., 2004; Hardy et al.,
2006). Worst among these was that from Shaltout et al. (1981) that attributed the death incidence of $25 \%$ among children in Kuwait with encephalopathy to the liberal use of kohl. All these recognized kohl brands as potential source of lead $(\mathrm{Pb})$ poisoning, except the findings from Tabbara and Burd (1987) when kohl was analyzed for microbial content, The reports on lead as a major constituents of the majority of kohl preparations, serve as the basis for elimination and setting standard for $\mathrm{Pb}$ and later other toxic elements (As, $\mathrm{Cd}, \mathrm{Hg}, \mathrm{Ni}$, Co) found equally as important in kohl preparations (http://en.wikipedia.org/wiki/kohl-cosmetics). All products must therefore strictly adhere to the regulations and must be well labeled for chemical constituents (FDA, 2006).

Despite all these, it had been reported that the use of kohl is still in vogue among the population of Saudi Arabia (Al-Kawajah, 1992). The same can easily be witnessed among different ethnic groups in Nigeria currently.

Corresponding Author: I.Y. Zakari, Department of Physics, Ahmadu Bello University, Zaria, Nigeria, Tel.: +2347066688961

This work is licensed under a Creative Commons Attribution 4.0 International License (URL: http://creativecommons.org/licenses/by/4.0/). 
Notwithstanding, simple observation of reports on kohl shows that researches are so far limited to products originating from countries of the Far East, Middle East and Asia. Despite the facts that North African and some West African countries, in particular Nigeria, had also been recognized as kohl consumers and producers (AlHazzaa and Krahn, 1995), reports on these products are rarely found. Furthermore, since the report from NHMH (2007) that recognized some few brands to carry false claims of $\mathrm{Pb}$ concentration, rarely has any effort been made to verify the claims of any labeled product. Moreover, literature review reveals that efforts are almost solely, concentrate on $\mathrm{Pb}$, other elements (As, Cd, $\mathrm{Hg}, \mathrm{Ni}, \mathrm{Cr}, \mathrm{Sb}, \mathrm{Co}$ ) of relevance in cosmetics seem to suffer neglect.

Not only is kohl use for cosmetic purpose, but also for medicinal and traditional reasons (Kapoor, 2007). The use of Kohl is still in vogue in the modern time as kohl products are now available even in the countries of US and Europe (Health Canada, 2006).

Later findings (Hardy et al., 2002; Al-Ashban et al., 2004; Hardy et al., 2006) also confirm the hazardous nature of kohl.

The aim of this study is therefore to analyze the mine kohl products indigenous to Nigeria for general elemental composition, but with particular interest in those of relevance. Imported products shall be analyzed for comparison purpose and verification of claim for the labeled elements.

Unfortunately, all the researches analyzed kohl for chemical composition, except that of Tabbara and Burd (1987), which ascertain the microbial content. The present investigations were therefore, undertaken to in addition characterize the radiological content of the Mined kohl products indigenous to Nigeria. This is necessary as radiation induced diseases (Cember, 1992) are as important as those of chemicals (Berne Convention, 1964). It is hoped that the research will provide vital information for the consumers, manufacturers and the government for economic health and legislative purposes. The analysis would be done through the determination of gross alpha and beta counts. The proportional counter EURYSYS MEASURE IN20 at the Centre for Energy Research and Training, Ahmadu Bello University CERT, ABU Zaria, Nigeria would be employed. CERCA and LEA laboratories in France certified all Measurement.

\section{MATERIALS AND METHODS}

The study area: This study covered the major Galena (kohl) deposits along the North East and South east trending belt between latitudes $4^{\circ} \mathrm{N}$ and $14^{\circ} \mathrm{N}$ and longitudes $3^{\circ} \mathrm{E}$ and $15^{\circ} \mathrm{E}$ (Fig. 1). Minor deposits of the North East extending to the North West were also studied as sources for local consumption. Geological map of Galena deposits in Nigeria is available in Department of Geology Ahmadu Bello University, ABU Zaria.

This research is an analytical and descriptive cross sectional study. Data collection is random and student's t-test with $\alpha=1$ and 5\% were appropriately used throughout for data analyses.

Sample collection: Twenty three kohl samples were collected from different mining ground (both major and minor) across the country Fig. 1. They were immediately wrapped in a three layer of polythene to avoid contamination. In this form the samples were transported to CERT ABU Zaria preparation and analyses.

Fifteen different brands of imported kohl products were purchased as normal consumer products from markets and cosmetic shops. Some of the specimens were in their paste form and others in powdery form. The choice of samples was at random across the six geopolitical zone of the country (Fig. 1).

Sample preparation: Samples were crushed each manually to fine powder using a quartz model No. 3 and mortar model No. 80320 all made by Tyler company, USA. The samples were then homogenized to grain size of less than $125 \mathrm{pm} .(0.3-0.5 \mathrm{mg})$ of the powder samples were each measured using the metler Toledo balance model AE 163 No. 1075 and for the preparation of pellets. The calibration of the weighing balance was done by the Mettler cooperation service unit laboratory, Columbus, OH, USA and certified for stability to about $0.00075 \mathrm{mg}$ before the commencement of this study. However, as recommended by the calibration organization, recalibration of the balance was undertaken with a known weight after every few sets of samples for quality assurance.

The weighted powders were each mixed with 3 drops of organic liquid binder and pressed after wards at 10 tons with hydraulic press (25.011 model), thus samples in powdered and paste form were directly made into pellets.

The pellets were carefully labeled, covered with mila and stored in partitioned samples storage plastic containers ready for both the XRF and the proportional counter (ERISYS MEASURE), $\alpha$ and $\beta$ counter technique.

Precaution: To avoid contamination both pestle and mortar were washed with detergent and sponge after which they were rinsed thoroughly with tap water, dried with an absorbent (towel) and then cleaned with acetone (E/65/457-1) using tissue paper. This was done before each sample was prepared. 


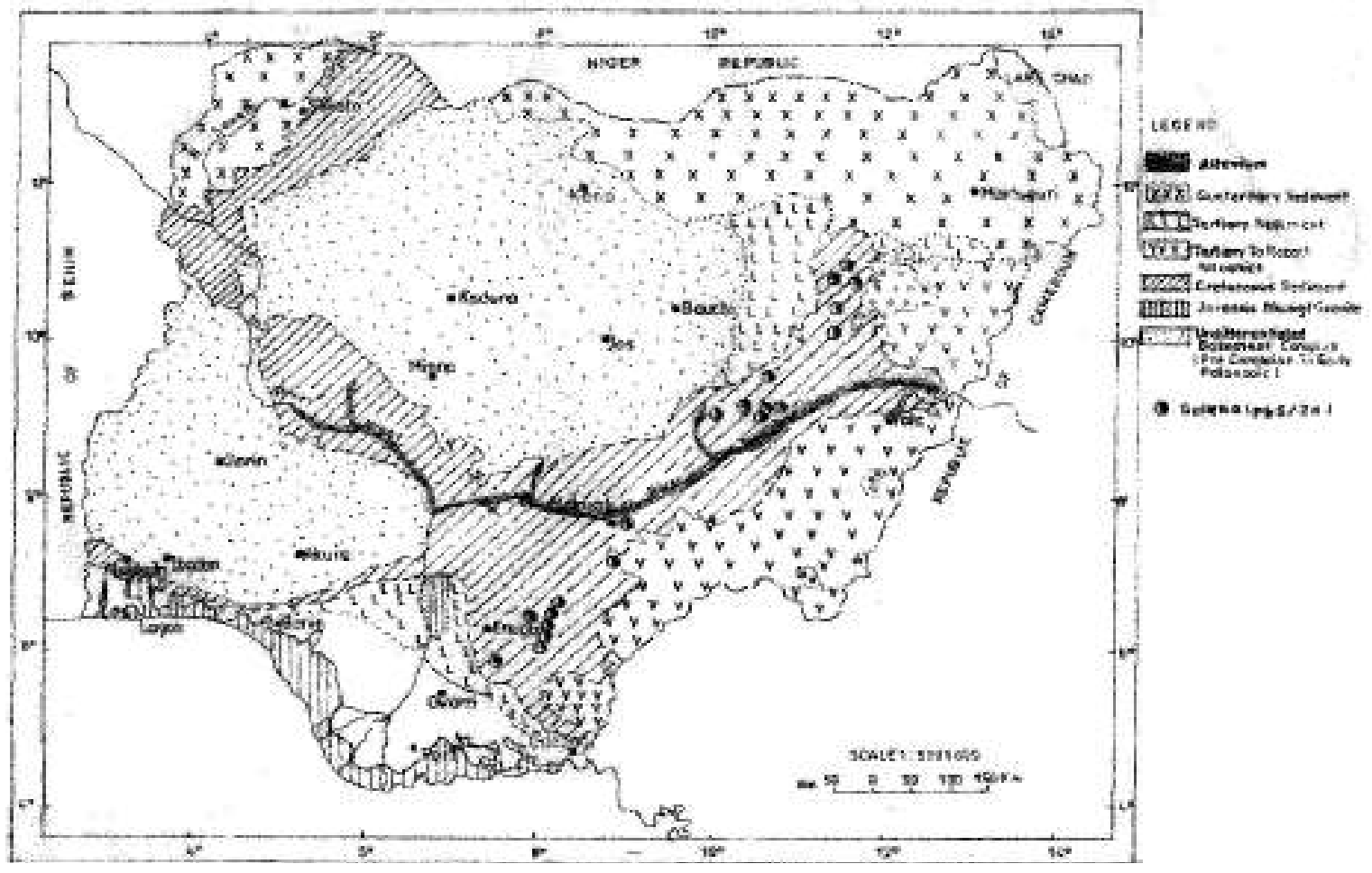

Fig. 1: Map of major galena deposit in Nigeria (Geology Department, ABU Zaria, Nigeria)

\section{RESULTS AND DISCUSSION}

Among the elements of interest only $\mathrm{Pb}$, was largely detected but with some few traces of as and $\mathrm{Ni}$ detected in the locally (Nigerian) mined samples Table 1.

Only one sample (NIG/Hdjia3) is $\mathrm{Pb}$ free, so that 22 out of the $23(95.6 \%)$ natural samples analyzed contain $\mathrm{Pb}$ in the concentration range of $0-43 \%$ with a mean concentration $27.23 \pm 16.70 \%$. Six out of the samples $(26 \%)$ have less than $1 \% \mathrm{~Pb}$ concentration. The entire 8 sample areas (S/N 8, 15, 16, 17, 18, 20, 21 and 22) observed with high $\mathrm{Pb}$ concentration ranging from $39-43 \%$ are known for mining activities in Nigeria, but none of the samples carries $\mathrm{Pb}$ up to and above $50 \%$ as reported by other investigators (Al Hazzaa and Krahn, 1995; Hardy et al., 2006).

A total of 15 other trace elements: $\mathrm{Cu}, \mathrm{Fe}, \mathrm{Mn}, \mathrm{Ni}$, $\mathrm{V}, \mathrm{Ti}, \mathrm{Th}, \mathrm{Nb}, \mathrm{Ca}, \mathrm{Zr}, \mathrm{Br}, \mathrm{Sr}, \mathrm{As}, \mathrm{Zn}$ and $\mathrm{Rb}$ were also detected together with $\mathrm{Pb}$ in all the samples as depicted by Fig. 1 and 2 . The observed higher $\mathrm{Pb}$ concentration compared with any other element present in each local sample was also seen in the imported kohl samples analyzed. This conforms to the earlier reports (AlHazzaa and Krahn, 1995; Kapoor, 2007) that identified majority of kohl preparations to be dominant with $\mathrm{Pb}$ and other elements at variable concentrations.

The unique presence of $\mathrm{V}, \mathrm{Nb}, \mathrm{Zr}, \mathrm{Br}$ and $\mathrm{Rb}$ as depicted by the Fig. 1 for the indigenous kohl samples

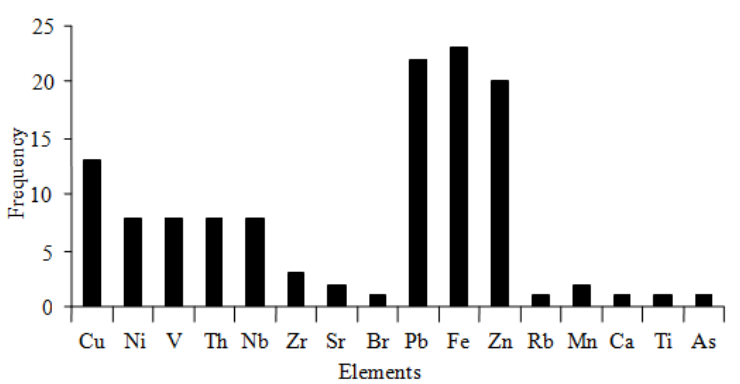

Fig. 2: Histogram of elemental frequency in indigenous samples

have never been reported as constituent of kohl and particular the presence of Th further suggests that Nigerian products may be of radiological risk as well.

In terms of conformity to $\mathrm{Pb}$ standard, Table 2 declares majority of the available kohl cosmetic products both local and imported in this region as unsafe because the recorded mean $\mathrm{Pb}$ value of $27.73 \%$ is significantly higher than the German standard (20 $\mathrm{ppm})$ which is the highest established safe limit $(\mathrm{p}<0.01)$ (Health Canada, 2009).

Other elements with atomic number less than 11 reported as constituent of kohl from other countries may be equally present in the samples, but not detected in the samples. This may be due to the inherit limitation of EDXRF technique. Antimony however can be concluded to be absent as it is among the elements in favor of the excitation source Viz Cd. 
Res. J. App. Sci. Eng. Technol., 7(14): 2970-2975, 2014

Table 1: Elemental analysis result for local kohl samples from Nigeria

\begin{tabular}{|c|c|c|c|c|}
\hline \multirow[b]{2}{*}{$\mathrm{S} / \mathrm{N}$} & \multirow[b]{2}{*}{ Sample code/location } & \multicolumn{3}{|c|}{ Elemental concentration $(\%)$} \\
\hline & & $\mathrm{Pb}$ & As & $\mathrm{Ni}$ \\
\hline 1 & NIG/Hdjial & $0.12 \pm 0.00$ & $0.081 \pm 0.00$ & ND \\
\hline 2 & NIG/Hdjia2 & $0.18 \pm 0.00$ & ND & ND \\
\hline 3 & NIG/Hdjia3 & ND & ND & ND \\
\hline 4 & NIG/BGwari1 & $25.90 \pm 0.27$ & ND & ND \\
\hline 5 & NIG/BGwari2 & $0.02 \pm 0.00$ & ND & ND \\
\hline 6 & NIG/Jos 1 & $28.50 \pm 0.28$ & ND & ND \\
\hline 7 & NIG/Jos 2 & $27.50 \pm 0.28$ & ND & ND \\
\hline 8 & NIG/Jos 3 & $39.00 \pm 0.50$ & ND & $0.26 \pm 0.00$ \\
\hline 9 & NIG/NsRwa 1 & $28.40 \pm 0.34$ & ND & ND \\
\hline 10 & NIG/NsRwa 2 & $32.80 \pm 0.34$ & ND & ND \\
\hline 11 & NIG/ZmFara & $0.12 \pm 0.00$ & ND & $0.02 \pm 0.00$ \\
\hline 12 & NIG/Mkurdi & $32.60 \pm 0.35$ & ND & ND \\
\hline 13 & NIG/BCH 1 & $27.50 \pm 0.28$ & ND & ND \\
\hline 14 & NIG/BCH 2 & $0.65 \pm 0.00$ & ND & ND \\
\hline 15 & NIG/AbKLk 1 & $42.20 \pm 0.50$ & ND & $0.20 \pm 0.00$ \\
\hline 16 & NIG/AbKLk 2 & $42.60 \pm 0.50$ & ND & $0.20 \pm 0.00$ \\
\hline 17 & NIG/AbKLk 3 & $43.40 \pm 0.51$ & ND & $0.23 \pm 0.00$ \\
\hline 18 & NIG/Maru & $42.30 \pm 0.50$ & ND & $0.27 \pm 0.00$ \\
\hline 19 & NIG/MRdun & $34.30 \pm 0.35$ & ND & ND \\
\hline 20 & NIG/Admwa & $40.90 \pm 0.50$ & ND & ND \\
\hline 21 & NIG/Eygba & $39.50 \pm 0.01$ & ND & ND \\
\hline 22 & NIG/Ameri & $39.50 \pm 0.50$ & ND & $0.22 \pm 0.00$ \\
\hline 23 & NIG/Ameka & $27.00 \pm 0.27$ & ND & ND \\
\hline \multicolumn{2}{|c|}{ Std. deviation (\%) } & 16.70 & $4.12 \times 10^{-4}$ & $8.95 \times 10^{-4}$ \\
\hline \multicolumn{2}{|c|}{ Mean } & 27.23 & $3.52 \times 10^{-3}$ & 0.23 \\
\hline
\end{tabular}

ND: Not detected

Table 2: Data of XRF analysis for Pb in indigenous (Nigerian) Kohl and imported kohl compared with standard values $(\alpha=1 \%$, one tailed)

\begin{tabular}{|c|c|c|c|c|c|c|}
\hline Sample/element & Conc. (ppm) & S.D. (ppm) & Min. standard values (ppm) & t-value & Frequency & Decision \\
\hline Indigenous & 277300 & 1608 & 20 & 16.51 & 22 & Significant \\
\hline Imported $(\mathrm{Pb})$ & 180900 & 1973 & 20 & 1.24 & & Significant \\
\hline Indigenous & 2256 & 120 & 49 & 15.31 & 08 & Significant \\
\hline Imported (Ni) & 1140 & 100 & 49 & 3.50 & & Significant \\
\hline Indigenous & 810 & 412 & 5 & 16.51 & 01 & Significant \\
\hline Imported (As) & 1630 & - & 5 & - & & Significant \\
\hline Indigenous & - & - & - & - & - & - \\
\hline Imported (Cr) & 7460 & 350 & 5 & 12.30 & & Significant \\
\hline
\end{tabular}

Arsenic is detected in only one of the sample (NIG/Hdjia1) at a concentration of $0.081 \%(810 \mathrm{ppm})$ with a mean of $35.22 \mathrm{ppm}$ and S.D. of $4.12 \mathrm{ppm}$. This value is much higher than the recommend limit for As $(5 \mathrm{ppm})$ in cosmetics according to the German standard (Table 2). The value is equally higher than the safe limit of $3 \mathrm{ppm}$ by Canada and US, respectively. Because this product also contains $\mathrm{Pb}$, the total risk involved in the use of this product is then $96 \%(92 \%$ $\mathrm{Pb}+4 \% \mathrm{As})$.

$\mathrm{Ni}$ is present in 7 of the local samples $(\mathrm{S} / \mathrm{N} \mathrm{6,13}$, $14,15,16,19$ and 22 , respectively) at concentrations ranging from 1970 to $2690 \mathrm{ppm}$ and a mean of $2256.25 \pm 8.95 \mathrm{ppm}$. Nickel is among the toxic elements whose safe limit in cosmetics has not been established. However Lilisa Saino et al. (2001) demonstrated that a level of $49 \mathrm{ppm}$ of $\mathrm{Ni}$ in cosmetic is high enough to cause skin allergic symptoms. Based on this, it is concluded that $\mathrm{Ni}$ concentration in the samples is higher that the $49 \mathrm{ppm}$ value at $2256.25 \pm 8.95 \mathrm{ppm}$ (Table 2). The minimum Ni concentration level (1970 ppm) detected in this study is a clear indication that none of the products from these region is safe for use as per Ni content. And for the products in general the possibility

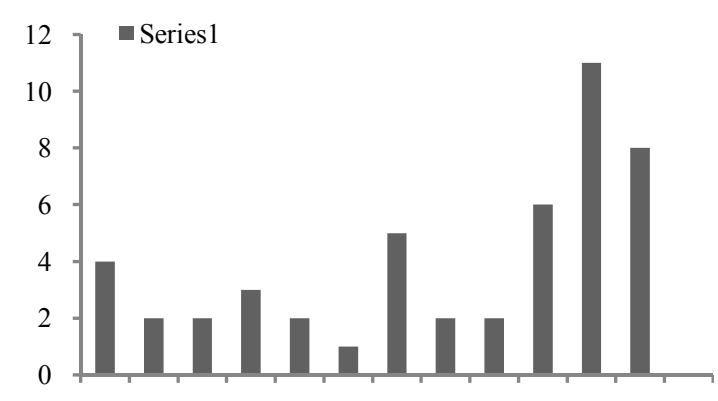

$\mathrm{Ca} \quad \mathrm{Br}$ NB ZR SR AS CR $\mathrm{Y} \quad \mathrm{Cu} \quad \mathrm{Pb} \quad \mathrm{Fe} \mathrm{Zn}$

Fig. 3: Histogram elemental concentration in imported kohl cosmetic samples

of Ni poisoning is $7 / 23 \approx 1 / 3=23 \%$. Because all the 7 samples also contains $\mathrm{Pb}(39.5 \leq \mathrm{Pb} \leq 43.4 \%)$, the total risk involved in the use of these products is then $26 \%$ $(8 / 31)$ (due to $\mathrm{Ni}$ ) $+71 \%$ (22/31) (due to) $\mathrm{Pb}$, to a total $=97 \%$ toxic.

Six out of the 15 imported kohl cosmetic samples are analyzed as $\mathrm{Pb}$ free. The remaining 9 has $\mathrm{Pb}$ concentrations ranging from $0.16-49 \%$ (Fig. 3). There are $6 / 9$ of them that contain higher $\mathrm{Pb}$ concentration 
Res. J. App. Sci. Eng. Technol., 7(14): 2970-2975, 2014

Table 3: Radiological data for the comparison of $\alpha$ and $\beta$ within indigenous (Nigerian) and imported kohl samples

\begin{tabular}{llllll}
\hline Products & $\alpha(\mathrm{cpm}) \times 10^{-3}$ & $\beta(\mathrm{cpm}) \times 10^{-3}$ & $\mathrm{t}$-cal & t-critical & Decision $\alpha=0.5 \%$ \\
\hline Indigenous $\overline{\mathrm{x}}$ & 283 & 5277 & 2.83 & 2.76 & Significant \\
S.D. & 189 & 4695 & & & \\
Imported $\overline{\mathrm{x}}$ & 283 & 3070 & 3.60 & & Significant \\
S.D. & 268 & 2883 & & & \\
\hline
\end{tabular}

that ranges from 27.8 to $49 \%$. The mean ( \pm S.D. $\%)$ concentration value of the samples was found to be $10.34 \pm 17.20 \%$ which is significantly higher than the $(0.002 \%)$ established safe limit for $\mathrm{Pb}$ (Student's t-test, $\mathrm{p}<0.01)$. Even the minimum detected value $(0.16 \%)$ is also found to carry $\mathrm{Pb}$ in excess of the safe limit. It is therefore, concluded that only the $\mathrm{Pb}$ free products $6 / 14$ $(43 \%)$ are considered safe for use in this regard, but again the observed presence of $\mathrm{As}, \mathrm{Cr}$ and $\mathrm{Ni}$ beyond the safety limits in these $\mathrm{Pb}$ free sample is a problem. Arsenic is present in a $\mathrm{Pb}$ free imported sample at a concentration of $1630>>5$ ppm the German safe limit and consequently very much was also found in the other five $\mathrm{Pb}$ free imported kohl samples at concentrations ranging from 3450-9270 ppm with a mean of $7460 \mathrm{ppm}$ (Fig. 2). This is much significantly higher than the 5 ppm recognized by Kang in 2002 and 2005 to cause skin allergies $(\mathrm{p}=0.005, \alpha=0.01)$. Thus the products are unsafe due to the presence of $\mathrm{Cr}$ only. The non detection of $\mathrm{Cr}$ in natural samples signifies its presences in artificial samples as a colorant. Again less regard is paid to the $\mathrm{Cr}$ control. Finally, Nickel was also observed in one of the samples with an observed $\mathrm{Cr}$ poison. The measured $\mathrm{Ni}$ is valued at a concentration of $1140 \mathrm{ppm}$ which is also higher than the recognized (49 ppm) to cause allergic symptoms (Lilisa Saino et al., 2001). Therefore, effect due to Ni intoxication is very much likely for the regular consumers of that product in addition to the $\mathrm{Cr}$ poison.

When the $\mathrm{Pb}$ concentrations of these imported samples are compared with those of the local samples, statistical analysis showed that there is no difference between the products $(\mathrm{p}<0.01)$ but for the additional radiological effect of the local samples and the toxic effects from $\mathrm{Cr}$ most pronounced in the imported $\mathrm{Pb}$ free samples.

Verification of claims: Out of the fifteen samples, nine were unlabeled. Two-thirds of these (1-6 inclusive) were $\mathrm{Pb}$ free. The remaining $1 / 3$ carry $\mathrm{Pb}$ far in excess of the safety margin (20 ppm). None of the labeled products carried $\mathrm{Pb}$ in conformity with the level carried by its label. While they were labeled to contain $\mathrm{Pb}$ below the safety level, it is found that their $\mathrm{Pb}$ content is far beyond the recommended limit of the $20 \mathrm{ppm}$ (with a mean of $178366 \mathrm{ppm}$; and standard deviation of 947 ppm).

Table 3 depict the statistical information on the $\alpha$ and $\beta$ emission from both local and imported products. It is clear from table that $\beta$ emission in the two products is considerably higher than the $\alpha \mathrm{s} \quad(\mathrm{p}<0.05)$. Thus suggesting that the great majority of the elements comprising the products are $\beta$ emitters of which majority are low $Z$ elements. A sample from Zamfara state shows an exceptionally high count in both $\alpha$ $(8998100 \mathrm{cpm})$ and $\beta(9315700 \mathrm{cpm})$. Products from this region therefore need a special attention this observation is consistent with the higher $\mathrm{Pb}$ concentrations obtained in kohl samples from that state Table 1 (S/N 18 and 19). Application of kohl from such sources is therefore very much likely to produce radiation damage to the cornea due to low penetration of the $\alpha$-particles. The internal tissue of the eyes are equally at risk as a result of the penetration of the $\beta$ particle of the relatively higher energy. Uptake of kohl via licking the lips, feeding and the direct ingestion from the younger ones, could therefore greatly increase $\alpha$-particle damages, due to direct contact with the tissues. It was also realized that there is no difference between the proportion of $\alpha$ to $\beta$ in both imported and local products (Table 3 ) and the same risk of radiation induced diseases should be expected following their usage. However, the non-existence of defined safety limits for these particles ( $\alpha$ and $\beta$ ) in Kohl, suggests the need for further research.

\section{CONCLUSION}

In conclusion, our findings reinforce the growing body of evidences that the majority of kohl preparation, irrespective of the formulae used in their preparation, carry substantial amount of $\mathrm{Pb}$ together with smaller quantities of other elements. $\mathrm{Pb}$ and $\mathrm{Ni}$ concentrations are quite comparable in the indigenous and imported products. It follows that the same risk of $\mathrm{Pb}$ and $\mathrm{Ni}$ induced diseases should be expected following their usage. The high concentration of $\mathrm{Cr}$ in some of the imported brands $(p<0.05)$ signifies the risk to which the patronage's of the brands concerned are exposed. The non-detection of $\mathrm{Cr}$ in local (Nigerian) samples indicates its presence as colorant in the imported samples and attention must be paid to $\mathrm{Cr}$ control. Finally, the particular presence of Th indicates that Nigerian products may be radiological hazard to health.

Again, this study, which to the best of our knowledge, was the first to describe the radioactive properties of Kohl, illustrated that, all forms of Kohl products are $\alpha$ and $\beta$ emitters with $\beta$ s' count rate substantially higher then $\alpha$ s'. Thus suggesting that majority of elements could be characterized as good beta emitters, composing of low z elements but for one of the samples from Zamfara State with an exceptionally high count in both $\alpha$ and $\beta$. It follows that 
Kohl products from Zamfara State require a special attention or better avoided as a cosmetic due to its likelihood to cause radiation damage. Uptake of kohl via licking the lips, feeding and the direct ingestion from the younger ones, could also greatly increase $\alpha$ particles damages, due to direct contact with the tissues. It was also realized that same risk of radiation induced diseases should be expected following their usage of both imported and local products. However, the nonexistence of defined safety limits for these particles in Kohl, suggests the need for further research.

\section{ACKNOWLEDGMENT}

The authors wish to thank Mr. Sunday Okoh and Malam Ado Gamba both of XRFA section of CERT, $\mathrm{ABU}$ Zaria for their technical assistance.

\section{REFERENCES}

Al-Ashban, R.M., M. Aslam and A.H. Shah, 2004. Kohl (surma): A toxic traditional eye cosmetic study in Saudi Arabic. Pub. Health, 118(4): 292-298.

Al-Hazzaa, S.A. and P.M. Krahn, 1995. Kohl: A hazardous eyeliner. Int. Ophthalmol., 19(2): 83-88.

Al-Kaff, A., A. Al-Rajhi, K. Tabbara and A. El-Tazigi, 1993. Kohl-the traditional eye liner: Use and analysis. Ann. Saudi Med., 13: 26-30.

Al-Kawajah, A.M., 1992. Al kohl used in Saudi Arabia: Extentent and possible lead toxicity. Trop. Geograph. Med., 44(4): 373-377.

Al-Saleh, I.A., C. Fellows, T. Delves and A. Taylor, 1993. Identification of sources of lead exposure to among children in Arrar, Saudi Arabia. Ann. Clin. Biochem., 30: 142-145.

Betts, P.R., R. Astley and D.N. Raine, 1973. Lead intoxication in children in Birmingham. Br. Med. J., 1(5850): 402-406.

Berne Convention, 1964. Life of the cell. 2nd Edn., Simson Shand Ltd London pp: 60-67.

Cember H., 1992. Introduction to Health Physics. 2nd Edn., McGraw-Hill Inc. Toronto pp: 220-231.

FDA US Food and drug Administration, 2006. Food drug and Cosmetic Act. Section 201 (1). Retrieved

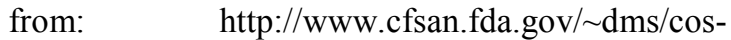
218.html.
Hardy, A.D., H.H. Sutherland and R. Vaishnav, 2002. A study of the composition of some eye cosmetic (Kohls) used in the United Arab Emirates. J. Ethnopharmacol., 80(2-3): 137-145.

Hardy, A.D., R.I. Walton, K.A. Myers and R. Vaishnav, 2006. Availability and chemical composition of traditional eye cosmetics ("Kohls") used in the United Arab Emirate of Dubai, Sharjah, Ajman, Umm Al-Quwain, Ras Al-Khaimah and Fukairah. J. Cosmet. Sci., 57(2): 107-125.

Hardy, A.D., R. Vaishnav, S.S. Al-Kharusi, H.H. Sutherland and M.A. Worthing, 1998. Composition of eye cosmetics (Kohl) used in Oman. J. Ethnopharmocol., 60(3): 223-234.

Health Canada, 2006. Consumer Information-health Concerns about Lead in Traditional Kohl. Retrieved form: http://www.bc-sc.gc.ca/cps-spc/ person/cosmet/koh_info-kohl-eng.php.

Health Canada, 2009. Consumer Product Safety, Draft Guidance on Heavy Metal Impurities in Cosmetics. File: Cafe001/documents/draftguidance on heavy metals impurities in cosmetics.htm.

Kapoor, V.P., 2007. Kohl and poisoning. Int. Soc. Environ. Botanist, 13(3).

Lilisa Saino E., R. Jolanki, E. Hakala and L. Kanary, 2001. Metal and arsenic in eye shadows. Contact Dermatitis, 42(3): 5-10.

Madany, I.M. and A.M. Salim, 1992. Lead levels in some eye cosmetics used in Bahrain. J. Environ. Sci. Health, 27(6): 1541-1547.

NHMH (New York City Department of Health and Mental Hygiene), 2007. Retrieved form: http://forum.chatdd.com/information-center/20119kohl-kajal-surmal.html.

Parry, C. and J. Eaton, 1991. Kohl: Lead hazardous eyeliner from the third world. Environ. Health Persp., 94: 121-133.

Shaltout, A., S.A. Yaish and N. Fernando, 1981. Lead Poisoning Encephalopathy in infants in Kuwait. Ann. Trop. Pediatr., 1: 209-215.

Snodgrass, G.J., D.A. Ziderman, V. Gulati and J. Richards, 1973. Letter: Cosmetic plumbism. Br. Med. J., 4(886): 230.

Tabbara, K.F. and E.M. Burd, 1987. Microbial content of kohl. Ann. Saudi Med., 7(3): 177-179.

Warley, M.A., P. Blackledge and P. O'Gorman, 1968. Lead poisoning from eye cosmetic. Brit. Med. J., 1(584): 117. 